Ковальчук Анна Сергіївна здобувач вищої освіти доктора філософії кафедри психології та особистісного розвитку Навчально-наукового інституту менеджменту та психології ДЗВО «Університет менеджменту освіти», вул. Січових Стрільців, 52-А, м. Київ, 04053, тел.: 044-481-38-00, e-mail: kovalchuk_anna1991@ukr.net, https://orcid.org/0000-0001-9027-2517

\title{
ПСИХОЛОГІЧНІ УМОВИ ФОРМУВАННЯ ОСОБИСТОСТІ ДИТИНИ В НЕПОВНІЙ СІМ'ї
}

Анотація. В даній статті розглядається тема психологічних умов формування особистості дитини в неповній сім'ї. Аналізуючи психологопедагогічну літературу 3 цієї проблеми ми згадуємо дослідників, які присвятили свої роботи неповним сім'ям. Неповна сім'я $\epsilon$ об'єктом дослідження через актуальність та поширеність цього явища. Розглядаємо психологічні умови, за яких дитина потрапляє до зони ризику у своєму розвитку та соціалізації в цілому. Неповна сім'я може складатися тільки 3 матері або тільки з батька і кожен сценарій розвитку подій має свої недоліки. Так виховна функція страждає найбільше і тому тягне за собою інші сімейні проблеми, конфлікти та відхилену поведінку дитини. Досить поширеним явищем $\epsilon$ психологічні проблеми, які виникають на фоні нестабільної ситуації, розвиваються тривога, страхи, невпевненість. Вчені зауважують, що у дітей в ситуації виховання одним із батьків виникає одна головна проблема - це відсутність прикладу конструктивних стосунків мама-тата, чоловікадружини, що в подальшому вплине на майбутні стосунки з протилежною статтю. Також, у нашій статті аналізуються проявлення у дітей, які є через дефіцит чоловічого впливу. Ми зазначаємо, що травматичною ситуацією для дитини більшою, ніж відсутність одного 3 батьків, $є$ переживання їх розлучення. Дитячій психіці важко усвідомити новий стиль взаємодії 3 батьками і їх новими стосунками між собою, це ставить дитину в глухий кут i породжує в ній психологічні і поведінкові відхилення. В кінці статті представляємо певні поради для батьків, які допомагають формувати позитивні внутрішньо сімейні стосунки та запобігти деструктивних проявлень та звести до мінімуму конфлікті ситуації між батьками та дітьми. Задля профілактики небажаних проявлень у поведінці дитини, слід приділяти більше уваги дітям, тримати емоційний зв'язок, приймати активну участь у житті та проблемах дітей.

Ключові слова: неповна сім'я, діти, батьки, психологічні умови.

Kovalchuk Anna Serhiivna Candidate of Higher Education, Doctor of Philosophy, Department of Psychology and Personal Development, Educational 
and Scientific Institute of Management and Psychology, University of Education Management, Sichovykh Striltsiv St., 52-A, Kyiv,04053, tel.: 044-481-38-00, e-mail: kovalchuk_anna1991@ukr.net, https://orcid.org/0000-0001-9027-2517

\title{
PSYCHOLOGICAL CONDITIONS OF FORMATION OF A CHILD'S PERSONALITY IN A INCOMPLETE FAMILY
}

\begin{abstract}
This article discusses the psychological conditions of the formation of the child's personality in a single-parent family. Analyzing the psychological and pedagogical literature on this issue, we mention researchers who have dedicated their work to single-parent families. The single-parent family is the subject of research due to the relevance and prevalence of this phenomenon. We consider the psychological conditions under which the child falls into the risk zone in their development and socialization in general. A single-parent family may consist of only the mother or only the father, and each scenario has its drawbacks. Thus, the educational function suffers the most and therefore entails other family problems, conflicts and rejected behavior of the child. Quite common are psychological problems that arise against the background of an unstable situation, develop anxiety, fears, insecurity. Scientists note that children in the situation of upbringing by one parent have one main problem - the lack of an example of a constructive relationship between mom and dad, husband and wife, which will further affect future relationships with the opposite sex. Also, our article analyzes the manifestations in children who are due to a lack of male influence. We note that a traumatic situation for a child greater than the absence of one of the parents is the experience of their divorce. It is difficult for the child's psyche to understand the new style of interaction with parents and their new relationships with each other, it puts the child in a dead end and creates psychological and behavioral disorders in it. At the end of the article we present some tips for parents that help to form positive internal family relationships and prevent destructive manifestations and minimize conflicts between parents and children. In order to prevent unwanted manifestations in the child's behavior, it is necessary to pay more attention to children, keep emotional connection, take an active part in the life and problems of children.
\end{abstract}

Keywords: single-parent family, children, parents, psychological conditions.

Постановка проблеми. Головним та незамінним інститутом соціалізації завжди буде залишатися сім'я. Однак, виникають ситуацію в житті, коли повноцінної сім'ї не виходить створити або за яких причин вона розпалась і тоді вихованням і розвитком дітей займається один з батьків.

Аналіз останніх досліджень і публікацій. Теоретичні надбання дослідження неповної сім'ї фігурують в зарубіжних та вітчизняних роботах, таких як А. Адлер, В. Бєлова, С. Голод, О. Захаров, А. Личко, Б.Кочубей, I. Кон, А. Макаренко, В. Титов та ін..

Мета статті. Теоретично обгрунтувати вплив неповної сім'ї на формування у дитини відхиленої поведінки. 
Виклад основного матеріалу. Неповною називається сім'я, яка складається 3 одного 3 батьків та 3 одним або кількома неповнолітніми дітьми [1]. Існує припущення, що діти, які виховуються в сім'я, де є тільки один із батьків, потрапляють до зони ризику у виникненні психологічних, педагогічних та соціальних проблем. У неповних сім'ях (де відсутній один 3 батьків) частіше, ніж у звичайних сім'ях, присутні авторитарні або занадто ліберальні відносини [2]. Вважається, що в сім'ях, де забезпеченням соціального благополуччя займається лише один з батьків, рівень достатку бажає кращого. Через постійну зайнятість, все менше з'являється часу на спілкування 3 дитиною, проведення 3 нею дозвілля, а тому дитина частіше знаходиться без постійної уваги і може піддатися сторонньому впливу інших осіб.

Серед ряду труднощів та негараздів, які можуть спіткати неповну сім’ю $\epsilon$ економічна чи матеріальна сторона $[3,54]$. Частіше за все бюджет у такій сім’ї складається лише із заробітку одного з батьків і якого не зажди вистачає на певні потреби. Існують випадки, коли саме через низький достаток сім’і діти вдаються до крадіжок, щоб заволодіти якимись благами. Такий життєвий шлях формує у дитини 3 малечку деструктивну поведінку та проблеми у соціумі.

У дітей 3 неповних сімей часто виникає цілий набір труднощів психологічного характеру. На думку І. С. Кона діти, які виросли без батька, мають знижений рівень домагань, у них вищий рівень тривожності, частіше зустрічаються невротичні симптоми, хлопчики 3 важкістю спілкуються 3 однолітками, гірше засвоюють істинно чоловічі ролі, але гіпертрофують деякі чоловічі риси: грубість, войовничість. Часто дитина починає бунтувати проти крайньої залежність від матері, або виростає пасивною, млявою, фізично слабкою [4].

Не секрет, що у таких сім'ях існують проблеми виховного впливу. Так, Відсутність одного 3 батьків може стати причиною неповноцінного, невдалого виховання дітей. У материнських неповних сім'ях, що зустрічається частіше за все, хлопчики не бачать приклада чоловічого поводження в родині, що сприяє формуванню в процесі їхньої соціалізації неадекватного уявлення про рольові функції чоловіка, батька. Це впливає й на соціалізацію дівчаток, які виховуються в материнських неповних сім'ях, спотворює їхні уявлення про рольові функції жінки, дружини, матері. Діти, що виховуються в сім'ях 3 одним із батьків, позбавлені приклада взаємин чоловіка й жінки в родині, що негативно впливає на їхню соціалізацію в цілому й на підготовленість до майбутнього сімейного життя зокрема [5, 119]. Відсутній приклад цілісної моделі конструктивних відносин. Сім’ї, де вихованням займається лише батько, також є певні недоліки. У чоловіків виховного потенціалу менше, ніж у жінок, тому дітям може не вистачати ласки, тепла, душевності, це може стати причиною для психологічних та комунікативних бар'єрів.

До психологічних умов формування особистості дитини в неповних сім'ях можна віднести наступне: 
- відсутність батька гостріше відчувають на собі хлопчики, і якщо в них немає близької авторитетної людини чоловічої статі, то вони можуть проявляти задиристу і неспокійну поведінку;

- дівчатка без батьківського виховання можуть відчувати себе невпевнено, страх, що з неї нікому постояти;

- $\quad$ при відсутності батька, хлопчики переймають якості характеру, властиві жінкам, а дівчаткам доводиться спостерігати як мама поєднує свою материнську роль 3 роллю відсутнього батька, i, як результат, психосексуальний розвиток таких дівчаток буде відрізнятися суперечливістю;

- $\quad$ для хлопчиків у неповних сім'ях часто існує більше число обмежень і заборон, ніж дівчат. На думку А. І. Захарова, в сім'ях хлопчиків велику строгість матерів можна інтерпретувати як реакцію на неприйняття в хлопчиків небажаних рис характеру колишнього партнера[6];

- якщо в сім'ї немає батька, у дітей виходить спотворений образ чоловіка, як правило, він збіднений або, навпаки, ідеалізовано, що стане причиною спрощеності або складнощів у відносинах з протилежною статтю;

- $\quad$ коли вихованням замається лише один із батьків, то діти бачать лише одну сторону виховання - або авторитарну, постійно караючу за проступки, або лояльну із вседозволеністю;

- $\quad$ у дітей 3 неповних сімей також спостерігається порушення самооцінки. У літературі часто зустрічається думка про феномен масової соціальної самотності дітей з неповних сімей та їх невисоку здібність будувати конструктивну міжособистісну взаємодію. $\mathrm{У}$ дітей 3 неповних сімей спостерігається також і деформація ідентифікації з батьками[7].

I.C. Кон, виявив, що діти, які виросли без батька, часто мають високий рівень тривожності, частіше зустрічаються невротичні симптоми, хлопчикам важко спілкуватися з однолітками, погано засвоюють чоловічі ролі, але гіпертрофують деякі чоловічі риси: грубість, войовничість. Дитина 3 неповної сім'ї частіше свариться з матір'ю, або виростає пасивним, млявим, фізично слабким [8, с.112].

Існують різні точки зору про те, яким чином може вплинути виховання дітей без батька, вони зводяться до того, що відсутність в сім'ї не просто батька, а, перш за все чоловіки є важливою передумовою відхилень у психічному розвитку дитини. Дефіцит чоловічого впливу в неповних сім'ях проявляється в наступному [9]:

- Порушується гармонійний розвиток інтелектуальної сфери, страждають математичні, просторові, аналітичні здібності;

- Процес статевої ідентифікації хлопчиків і дівчаток робиться менш чітким; 
- Відбувається труднощі навчання підлітків навичкам спілкування 3 представниками протилежної статі;

- Стає можливим формування надлишкової прихильності до матері, оскільки відсутній член сім'ї, який міг би «відірвати» дитину від матері, вивести його в більш широкий світ.

Дослідник А. С. Подільський відзначає ряд таких типових ускладнень, що зустрічаються у дітей з неповної сім'ї, як почуття самотності, втрата віри в близьких людей, втрата відчуття безпеки, емоційна неврівноваженість, виникнення почуття власної неповноцінності, хвороблива реакція на оціночні судження, підвищена ранимість дитини $[10,46]$.

3 точки зору I. Лангмейер i 3. Матейчек, найбільша небезпека для розвитку дитини, настає тоді, коли немає матері (батьківська сім'я) особливо в ранньому віці. Від матері залежить задоволення в основному всіх психічних потреб дитини - вона являе основу для відносини дитини до людей, для його довіри до навколишнього світу, перш за все саме мати створює для дитини «будинок» і «затишок». Часто в неповній батьківській родині рідну матір дитини вдається замінити іншою жінкою мачухою, або яким-небудь 3 родичів дитини (старша сестра, бабуся, тітка). У більшості випадків дитині приділяється достатньо, або занадто багато уваги, любові і турботи. У таких сім'ях частіше, виникають різні конфлікти, ніж у природному, так як взаємозв'язку тут є більш напруженими [11].

На думку Е.А. Осипової, у дівчаток висока ймовірність прояву емоційних розладів, переважно істеричного властивості, а у хлопчиків невпевненості в собі і страхів в результаті надмірної опіки і тривожності 3 боку дорослих, які вигідно відрізняються батька. Крім того, ймовірні проблеми в спілкуванні з однолітками своєї статі. Можливі у хлопчиків і протестні форми поведінки, так як вони болісно, загострено намагаються утвердитися в чоловічої ролі, компенсуючи цим брак спілкування з батьком. Якщо емоційний контакт з одним з батьків збережений, то ситуація може розвиватися більш благополучно. Якщо немає, тоді стресова, «психотравмирующая» ситуація, пов'язана 3 розлученням батьків, може тривати для дитини кілька років. I якщо вчасно не надати допомогу, то стрес може перейти в стійку шкільну дезадаптацію [12].

Проте, одна справа, коли діти виростають в неповній сім'ї, а інша, коли переживають розлучення батьків. В такій ситуації дитина потрапляє в психологічно нестабільну ситуацію, коли батьки занурюються у вирішення власних проблем, а вона залишається наодинці зі своїми переживаннями. Це тягне за собою конфлікти не лише між батьками, але й дитини з батьками. У дитини формується висока тривожність, яка пов'язана з будуванням нових відносин 3 кожним із батьків, тримаючи нейтралітет та не втручаючись у їх відносини. Можливо й таке, коли дитина відчуває гнів до одного з батьків, хто став ініціатором розлучення або до обох через те, що допустили ситуацію розлучення. Діти втрачають почуття опори та довіри до світу і починають вороже ставитися до оточуючих, поводитись деструктивно, шукати небезпечні заняття для розрядки емоцій, проявляти девіантну або навіть 
делінквентну поведінку.

Таким чином, для того, щоб максимізувати позитивний i звести до мінімуму негативний вплив сім'ї на виховання дитини необхідно пам'ятати внутрішньосімейні психологічні чинники, які мають виховне значення [13]:

- Брати активну участь в житті сім'ї;

- Завжди знаходити час, щоб поговорити з дитиною;

- Цікавитися проблемами дитини, приймати активну участь у всі виникаючі в іiі житті складнощів і допомагати розвивати свої вміння та таланти;

- Не здійснювати психологічного натиску, допомагаючи їй тим самим самостійно приймати рішення;

- Мати уявлення про різні етапи в житті дитини;

- Поважати право дитини на власну думку;

- Вміти стримувати власні емоції i ставитися до дитини як до рівноправного партнера, який просто поки що володіє меншим життєвим досвідом;

- 3 повагою ставитися до прагнення всіх інших членів родини робити кар'єру і самовдосконалюватися.

Висновки. Таким чином, проаналізувавши всі чинники та фактори впливу неповної сім’ї на розвиток та становлення особистої дитини, можна сказати, що діти в таких сім'ях потрапляють до зони ризику і потребують більш пристальної уваги з боку батьків та близьких задля їх повноцінного розвитку.

\section{Лimepamypa:}

1. Маннапова К. Р. Неповна сім'я як чинник, що впливає на формування життєздатності підлітків / К. Р. Маннапова // Вісник Харківського національного університету імені В. Н. Каразіна. Серія : Психологія. - 2011. - № 959, Вип. 46. - С. $105-$ 108. - Режим доступу: http://nbuv.gov.ua/UJRN/VKhIPC_2011_959_46_25.

2. Стуколова М. Семейные конфликты и их особенности // Вопросы психологии. 2000. - № 4. - С.24-29.

3. Фигдор Г. Дети разведенных родителей: между травмой и надеждой. - М.: Наука, 1995. $-376 \mathrm{c}$.

4. Кон И.С. Психология юношеского возраста.- М: Просвещение, 1979.- 178 с.

5. Юрченко І.В., Психологічна характеристика неповної сім’ї // Альманах студентського наукового товариства «Актуальні питання психологічної науки». - Рівне: РДГУ, 2008. - Вип. 1. - С. 119-124

6. Захаров А.И. Происхождение детских неврозов и психотерапия. - М.: ЭКСМОПресс, 2000.- 265 с.

7. Матейчик 3. Некоторые психологические проблемы воспитания детей в неполной семье // под ред. Ершова Н.М. Воспитание детей в неполной семье.- М.: Прогресс, 1980.C. $70-98$

8. Джинотт Х.Г. Дети и мы. - СПб.: Кристалл, 2003.

9. Василькова, Ю.В. Методика и опыт работы социального педагога. - М.: Академия, 2001. $-160 \mathrm{c}$.

10. Подольский А. С. Воспитание детей в неполных семьях как психологопедагогическая проблема /А. С. Подольский // Гуманизация образования - Проблемы и 
перспективы: Сб. Научн. Докладов Международной научно-методической конференции. 2008. - C. 44-48.

11. Лангмейер Й., Матейчек 3. Психическая депривация в детском возрасте / пер.

Г.А. Овсянникова. - Прага : Авиценум, 1984. - 334 с.

12. Осипова Е.А. Дети из нетипичных семей / Е.А. Осипова // Праблемы выхавання. - 1999. - № 2. - С. 63-66.

13. Олифирович Н.И., Зинкевич-Куземкина Т.А., Велента Т.Ф. Психология семейных кризисов. - СПб: Речь, 2006.

\section{References:}

1. Mannapova, K.R. (2011). Nepovna sim'ya yak chynnyk, shcho vplyvaye na formuvannya zhyttyezdatnosti pidlitkiv [Incomplete family as a factor influencing the formation of adolescent viability]. Visnyk Kharkivs'koho natsional'noho universytetu imeni V.N. Karazina. Seriya: Psykholohiya - Bulletin of V.N. Karazin Kharkiv National University. Series: Psychology, 46 (959), 105-108. Retrieved from http://nbuv.gov.ua/UJRN/VKhIPC_ 2011_959_46_25 [in Ukrainian].

2. Stukolova, M. (2000). Semeynyye konflikty i ikh osobennosti [Family conflicts and their features]. Voprosy psikhologii-Questions of psychology, 4, 24-29 [in Russian].

3. Figdor, G. (1995). Deti razvedennykh roditeley: mezhdu travmoy i nadezhdoy [Children of Divorced Parents: Between Trauma and Hope]. M.: Nauka [in Russian].

4. Kon, I.S. (1970). Psikhologiya yunosheskogo vozrasta [Psychology of adolescence]. M: Prosveshcheniye [in Russian].

5. Yurchenko, I.V. (2008). Psykholohichna kharakterystyka nepovnoyi sim'yi [Psychological characteristics of single-parent family]. Al'manakh student-s'koho naukovoho tovarystva "Aktual'ni pytannya psykholohichnoyi nauky» - Almanac of the student scientific society «Actual issues of psychological science», 1, 119-124. Rivne: RDHU [in Ukrainian].

6. Zakharov, A.I. (2000). Proiskhozhdeniye detskikh nevrozov i psikhoterapiya [The origin of childhood neuroses and psychotherapy]. M.: EKSMO-Press [in Russian].

7. Mateychik, Z. (1980). Nekotoryye psikhologicheskiye problemy vospitaniya detey v nepolnoy sem'ye [Some psychological problems of raising children in an incomplete family]. Vospitaniye detey $v$ nepolnoy sem'ye - Raising children in an incomplete family. N.M. Yershova (Ed.). M.: Progress [in Russian].

8. Ginott, H.G. (2003). Deti i my [Children and us]. SPb.: Kristall [in Russian].

9. Vasilkova, Yu.V. (2001). Metodika i opyt raboty sotsial'nogo pedagoga [Methodology and work experience of a social teacher]. M.: Akademiya [in Russian].

10. Podolskiy, A.S. (2008). Vospitaniye detey v nepolnykh sem'yakh kak psikhologopedagogicheskaya problema [Raising children in incomplete families as a psychological and pedagogical problem]. Gumanizatsiya obrazovaniya - Problemy i perspektivy - Humanization of education - Problems and prospects: Collection of Scientific Reports of the International Scientific and Methodological Conference. (pp. 44-48) [in Russian].

11. Langmeyer, Y., \& Mateychek, Z. (1984). Psikhicheskaya deprivatsiya $v$ detskom vozraste [Psychic deprivation in childhood]. (G.A. Ovsyannikova, Trans). Praga: Avitsenum [in Russian].

12. Osipova, E.A. (1999). Deti iz netipichnykh semey [Children from atypical families]. Prabliemy vychavannia - Problems of upbringing, 2, 63-66 [in Russian].

13. Olifirovich, N.I., Zinkevich-Kuzemkina, T.A., \& Velenta, T.F (2006). Psikhologiya semeynykh krizisov [The psychology of family crises]. SPb: Rech [in Russian]. 